\title{
Corrupt Actions and Forest Loss: A Cross-National Analysis
}

\author{
Jamie M Sommer ${ }^{1}$ \\ ${ }^{1}$ State University of New York at Stony Brook, Stony Brook, New York USA \\ Correspondence: Jamie M. Sommer, Department of Sociology, State University of New York at Stony Brook, Stony \\ Brook, NY, United States of America.
}

Received: August 13, 2018

Accepted: September 11, $2018 \quad$ Available online: September 25, 2018

doi:10.11114/ijsss.v6i10.3534

URL: https://doi.org/10.11114/ijsss.v6i10.3534

\begin{abstract}
Extant literature documents the negative environmental impacts of corruption on forest loss. More recently, research has shown that both grand and petty corruption are associated with higher levels of forest loss in low- and middle-income nations. However, the extant research neglects to assess how different types of grand and petty corruption impact forest loss. To address the gap in the literature, this article differentiates the effect of various types of corrupt actions on forest loss. Ordinary Least Squares (OLS) regression for a sample of 87 low- and middle-income nations from 2000 is used to test if grand corrupt actions, namely embezzlement and bribes, and petty corrupt actions including theft and corrupt exchanges are related to increased forest loss. The dependent variable uses satellite forest data from 2001 to 2014. Results show that embezzlement, bribes, theft, and corrupt exchanges all impact forest loss, which suggests that policy measures to curb corruption should take a holistic approach to corruption, rather than rely on individual interventions.
\end{abstract}

Keywords: corrupt actions, embezzlement, bribes, theft, corrupt exchanges, cross-national

\section{Introduction}

\subsection{Corruption and Forest Loss}

Corruption is a major barrier to forest conservation (Sundström, 2016a; Cavanagh, 2012; Iverson, Chhetry, Francis, Gurung, Pain, \& Seely, 2005). Approximately 23 billion dollars of wood are cut illegally each year (Transparency International, 2018; World Bank, 2018). Forest loss contributes to climate change, biodiversity loss, and it robs people of their livelihoods - especially in low- and middle-income nations. Various researchers have made the connection between forest loss and corruption in low- and middle-income nations cross-nationally (Meyer, van Kooten, \& Wang, 2003; Barbier, Damania, \& Léonard, 2005; Bulte, Damania, \& Lopez, 2007; Laurance, 2007; Koyuncu \& Yilmaz 2009, 2013; Sundström, 2016b; Sommer, 2017).

In one of the first cross-national studies focusing in forest loss and corruption, Meyer, van Kooten, and Wang (2003) find that the World Bank's World Governance Indicator (WGI) control of corruption is associated with forest loss in 117 nations. Later, Barbier, Damania, and Léonard (2005) find that WGI control of corruption is related to decreased agricultural land expansion (which is a leading cause of forest loss) for low- and middle-income tropical countries. Bulte, Damania, and Lopez (2007) find similar results for nine Latin American countries. Using different corruption data, Laurance (2007) finds that Transparency International's Corruption Perception Index (CPI) is related to forest loss in 12 Asian nations.

After 2007, research on forest loss and corruption has become more complex, using various aggregate measures of corruption in the same analyses. Most notably, Koyuncu and Yilmaz $(2009,2013)$ find a positive and significant relationship between forest loss and the CPI, the International Country Risk Guide (ICRG) index, the Business Intelligence (BI) index, and the WGI control of corruption indicator. However, there have been contradictory cross-national findings between corruption and forest loss. For instance, Shandra, Shircliff and London (2011) and Aisbett, Doupe, and Tacconi (2013) find no relationship between corruption and forest loss. Sundstorm (2016a), as well as others such as Meehan and Tacconi (2017) and Barret, Gibson, Hoffman, and McCubbins (2006) suggest these inconsistent findings are due to a lack of theoretical frameworks of corruption and an absence of disaggregated data. In response, Sommer (2017) uses corruption data from the Varieties of Democracy (V-Dem) (2016) and the Quality of Governments (QoG) institute to test how disaggregated data on executive or grand corruption, and public sector or petty corruption impacts forest loss. Using data for 87 low- and middle-income countries Sommer (2017) finds that both 
measures of corruption are related to forest loss.

While the aforementioned research represents an important shift in corruption and forest loss studies, it does not address how specific corrupt actions impact forest loss cross-nationally. While the connections between corruption and forest loss are well-studied, there is a gap in the literature when it comes to more specific ideas of corruption and forest loss, which limits our ability to understand how different types of corruption may impact forest loss and what this looks like on the ground theoretically. Therefore, though it is helpful to think of corruption in terms of government sectors and as grand or petty, it is also necessary to conceptualize corruption in terms of measurable actions for current policy decisions and theoretical framings of forest loss. Newly available data from V-Dem, which breaks down grand and petty corruption into bribes, embezzlement, theft, and corrupt exchanges, makes such an analysis possible. Therefore, building off of the above research, the current analysis uses Ordinary Least Squares (OLS) regression for a sample of 87 low- and middle-income nations from 2000, to test if grand corrupt actions, namely embezzlement and bribes, and petty corrupt actions including theft and corrupt exchanges are related to increased forest loss. The dependent variable uses satellite forest data from 2001 to 2014 .

The article is organized in the following way. First, the theoretical framework is discussed by defining each corrupt action. Second, there is a section on how corrupt actions should be related to forest loss. Third, there is a review of the methodology, data, and findings. Lastly, the article concludes by summarizing the findings, discussing potential limitiations, and suggesting policy recommendations and future research.

\subsection{Background}

Corruption is commonly defined as the 'misuse of public power for private gain' (see Transparency International, 2018). The definition is intentionally vague in an attempt to capture the multifaceted and transforming meanings of this concept (Sundström, 2016a; Meehan \& Tacconi, 2017; Tacconi, Downs, \& Larmour, 2009). While corruption is something that 'we recognize when we see it,' it also varies by time and place, making it difficult for scholars and practitioners to agree on a definition. Most scholars, especially when studying corruption in the forestry sector, move past this challenge by choosing a theoretical frame for understanding corruption (please see Sundström (2016a) for a full review of all recent literature concerning corruption and forest loss). These include thinking of corruption in terms of collusive and non-collusive, political and public, or grand and petty (Callister, 1999; Koyuncu \& Yilmaz, 2009; Sommer, 2017).

The current study employs a theoretical frame in part developed by Sundström (2016a), which elaborates how corruption is rampant in government authorities, and can be broken down into grand corruption, which captures corruption by the executive branch, and petty corruption, which refers to corruption in the public sector (Agrawal, 2007; Halkos, Sundstrom, $\&$ Tzeremes, 2013). Following previous research, executive or 'grand' corruption is defined as bribes and embezzlement that happen at the level of rulers and the cabinet, and public sector or 'petty' corruption as theft and corrupt exchanges that occurs among low- and mid-level public officials (Coppedge, et al. 2016, 67). For instance, petty corruption could entail a situation where an illegal exchange takes place between a public official and a logger to not enforce a regulation, where grand corruption can entail a company bribing an executive official to enact a concession that allows logging in a previously protected area (Callister, 1999; Sundström, 2016a; Meehan \& Tacconi, 2017).

However, this study is less concerned with how these government bodies impact corruption and more interested in how corrupt actions in both grand and petty forms impact forest loss. Therefore, the following section details how bribes, embezzlement, theft, and corrupt exchanges should impact forest loss in an attempt to shift the discussion away from corruption as a vague and all-encompassing concept to a series of measurable actions. Conceptualizing corruption as actions rather than an overarching term may help in generating more specific policy recommendations that can identify what corrupt actions are possible, how they impact forest loss, and what types of ameliorative policies we should focus on.

\subsection{Corrupt Actions and Forest Loss}

Corrupt actions should impact forest loss in several ways. The following section is a review of how the four main corrupt actions - bribes, embezzlement, corrupt exchanges, and theft—should impact forest loss with examples for each. These are summarized in Table 1 below. 
Table 1. The Relationships Between Corrupt Actions and Forest Loss

\begin{tabular}{|c|c|c|c|}
\hline Corrupt Action & & Example & Key Sources \\
\hline & Bribes & Peru & Sears \& Pinedo-Vasquez, 2011; Urrunaga et al., 2012; Putz \\
\hline Grand & & & \& Romero, 2015 \\
\hline Corruption & Embezzlement & Malaysia & $\begin{array}{l}\text { Laurance, 2004, 2001; Speechly \& Van Helden, 2012; } \\
\text { Straumann, } 2014\end{array}$ \\
\hline & Corrupt & Democratic Republic of the & Butler, 2013; Debroux et al., 2007; Siebert \& Elwert 2004 \\
\hline Petty & Exchanges & Congo & \\
\hline Corruption & Theft & Costa Rica & Miller 2011; Gore et al. 2013; \\
\hline
\end{tabular}

1.3.1 Bribes

Under the framework of grand corruption, executive officials can give companies and timber barons 'preferential' treatment for large bribes or payoffs (Miller 2011; Currey \& Ruwindrijarto, 2001). Through this process corrupt leaders and timber companies make deals to draw in profits (Callister, 1999). Officials may accept or ask for bribes to eliminate or soften laws and restrictions, allowing loggers to access areas previously off limits (Callister, 1999). These decrees may also lift protections on rare and valuable tree species, especially in tropical forests (Sundström, 2016a; Koyuncu \& Yilmaz, 2009). Moreover, an official may ask for a bribe to create forestry concessions, making logging more profitable. For example, in Peru in 2000, several logging concessions gave power over forestland to large timber companies even though most of the forestland in Peru was occupied by indigenous people (Sears \& Pinedo-Vasquez, 2011; Urrunaga et al., 2012; Putz \& Romero, 2015). Logging concessions, permits, and contracts are often directly controlled or held by the powerful political and economic ruling class, which support corporate logging for export, and should result in increased deforestation (Laurance, 2004; Speechly \& Van Helden, 2012; Straumann, 2014). In an attempt to reform forest policy in Peru to reduce these environmentally damaging concessions, laws were later adopted to incorporate a free trade treaty with the United States that would encourage legal forest trade (Urrunaga et al., 2012; Oliveira et al., 2007). However, following the deal, several executive mandates created loopholes to convert forestland into agricultural land, allowing for further executive corruption (Urrunaga et al., 2012). Despite civilian protest, which resulted in violence, the executive sector was able to defend its orders for their own monetary gain (Oliveira et al., 2007).

\subsubsection{Embezzlement}

Embezzlement is another corrupt action within the framework of grand corruption. Executive powers can embezzle, or misappropriate, funds generated from the profit of the forests in the form of private illegal gains (Palo, 2004; Finer et al., 2014). Although these illegal actions can be taken to courts, many executive officials have the power to protect business elites from any penalties (Palo, 2004). These instances are found in areas such as Indonesia, Cambodia, and the Democratic Republic of the Congo, and often result in the clearing of large expanses of forests (Prager \& Thisse, 2012; Søreide, 2007; Sundström, 2016a). For example, in Malaysia, a lack of a transparent and accountable systems of governance allowed corrupt executive politicians to lease out licenses for logging to corporations and private individuals at the expense of Malaysian land owners (Laurance, 2004; Speechly \& Van Helden, 2012; Straumann, 2014). Malaysian leaders often engaged in money laundering and tax evasion to cover up dirty money from these embezzlements (Straumann, 2014). Therefore, executive embezzlement should result in more forest loss.

\subsubsection{Corrupt Exchanges}

Within the framework of petty corruption, public sector officials are often in close proximity to forests which allows for more interaction with loggers and companies (Siebert \& Elwert 2004). These frequent interactions can sometimes translate into corrupt exchanges which benefit underpaid forestry officials and loggers seeking to pay less for permits or $\log$ on protected land (Sommer, 2017). For example, in 2002, the Democratic Republic of the Congo created a moratorium against commercial logging; however, loggers found their way around the suspension by bribing officials for artisanal permits (permits usually reserved for community logging) (Butler, 2013; Debroux et al., 2007). These moratoriums allow logging companies to target endangered tree species for export to areas such as China and Europe (Butler, 2013). Although the government has recently implemented other initiatives such as the Agricultural and Rural Sector Rehabilitation Support Project (PARSAR), officials may engage in corrupt exchanges so that companies and militiamen can circumvent such laws (Severin, 2010; Butler, 2013). This process can lead to increased forest loss, especially if corrupt exchanges undermine issues with scarcity (Robbins, 2000).

\subsubsection{Theft}

Public officials can engage in the theft of resources generated from logging, which can make it appear on paper like less 
forests were cut through falsified documents. Forestry officials may also choose to not stamp permits, making it difficult to track logger's actions while also making funds easier to steal (Miller, 2011). This type of collusion with loggers can increase false documentation, allowing larger amounts of trees to be harvested (Gore et al., 2013). Even nations that have become very successful in environmental protection are at risk for petty theft, which can increase forest loss. For example, in Costa Rica, forestry officials often have low salaries and may see their government position as a gateway to making extra money (Miller, 2011). Likewise, in Costa Rica corruption in the forestry sector is normalized and officials know what colleagues and loggers they can collaborate with for extra money (Miller, 2011). Moreover, forestry officials may not want to report corrupt behaviors, as reporting leads to extra paperwork for violations, which can leave acts underreported (Arias, 2005). In addition, officials may also intercept funds used for forestry protection, reducing the quality of state conservation measures (Sommer, 2017). In sum, theft can skew forestry figures and misplace environmental funds, which should increase forest loss. Based on the above relationships, it is hypothesized that bribes, embezzlement, corrupt exchanges, and theft will correspond with higher levels of forest loss.

\section{Method}

2.1 Sample

The sample consists of 87 low and middle-income nations. Low and middle-income nations are defined using the World Bank Atlas method (Shandra et al., 2016). Nations are included in the sample if they have a GNI per capita of 12,475 USD or less (World Bank, 2015). High income nations are excluded because the dynamics of forest loss differ in these countries, and therefore are considered separate from low and middle-income nations in cross-national analyses (Shandra et al. 2011). Moreover, low and middle-income nations generally have higher levels of forest loss and corruption (Sommer, 2017). Therefore, the sample is restricted to low and middle-income nations ${ }^{1}$.

\subsection{Statistical Model}

The current analysis uses ordinary least squares regression to analyze the effects of corrupt actions on forest loss. Researchers use OLS regression to estimate the factors that impact deforestation when longitudinal data are not available (e.g., Shandra et al., 2010, 2016; Jorgenson \& Burns, 2007). The formula for OLS regression is:

$y_{i}=a+b_{1} X_{1}+b_{2} X_{2} \ldots+b_{k} X_{k}+e_{i}$

where,

$y_{i}=$ dependent variable for each country,

$a=$ the constant,

$b_{1}$ to $b_{\mathrm{k}}=$ unstandardized coefficients for each independent variable,

$x_{\mathrm{k}}=$ independent variables for each country, and

$e_{i}=$ error term for each county.

All models have been checked to ensure adherence to all regression assumptions (Shandra et al., 2016; Allison, 1999). First, variance inflation factor scores, reported in table 3, reveal no potential problems with multicollinearity (York, Rosa, \& Dietz, 2003). Second, variable transformations are used when appropriate to correct for non-normally distributed variables and are noted in table 2 (Tabachnick \& Fidel, 2013). Third, based on standardized residuals, it appears that any potentially extreme cases are not biasing the results (Tabachnick and Fidel, 2013). Fourth, there seems to be issues associated with heteroscedasticity based on Breush-Pagan statistics for each model, therefore, robust standard errors are used (Tabachnick \& Fidel, 2013).

\subsection{Dependent Variable}

Forest Loss: Cross-national research on forest loss often uses data from the United Nation's Food and Agriculture Organization's Global Forest Resources Assessment (e.g., Shandra et al. 2011, 2016). However, some of these data are gathered using collection methods that differ by nation (Grainger, 2008). Forestry statistics in some nations are more reliable than others that are estimated from remote sensing surveys or extrapolated from outdated forestry inventories (Food and Agriculture Organization, 2015; Grainger, 2008). To correct for these issues this analysis uses newly available data on forest loss from high resolution satellite imagery in order to eliminate the potential source of error (World Resources Institute, 2016; Hansen et al., 2010) ${ }^{2}$, these data are obtained from the World Resources Institute (2016) Global Forest Watch web page. Forest loss is calculated by dividing the provided number of hectares of forest losses in a country from 2001 to 2014 by the country's total forest size in hectares for 2000, yielding the change of forest loss over this period of time (Rudel et al., 2016; Rudel 2017).

One limitation of these data is that the imagery is only available for the time period of 2001-2014, although this type of measurement is in line with past cross-national research (Shandra, 2007; Shandra et al., 2016). Another limitation of 
these data is that they are not suitable for over time comparisons using panel regression methods (Rudel, 2017). This variable is logged due to skewness. Table 2 displays a bivariate correlation matrix for all the variables used in the analysis. Unless otherwise noted, all data may be obtained from the World Bank (2015).

Table 2. Descriptive Statistics and Bivariate Correlation Matrix for Deforestation Analysis ( $\mathrm{N}=87)$

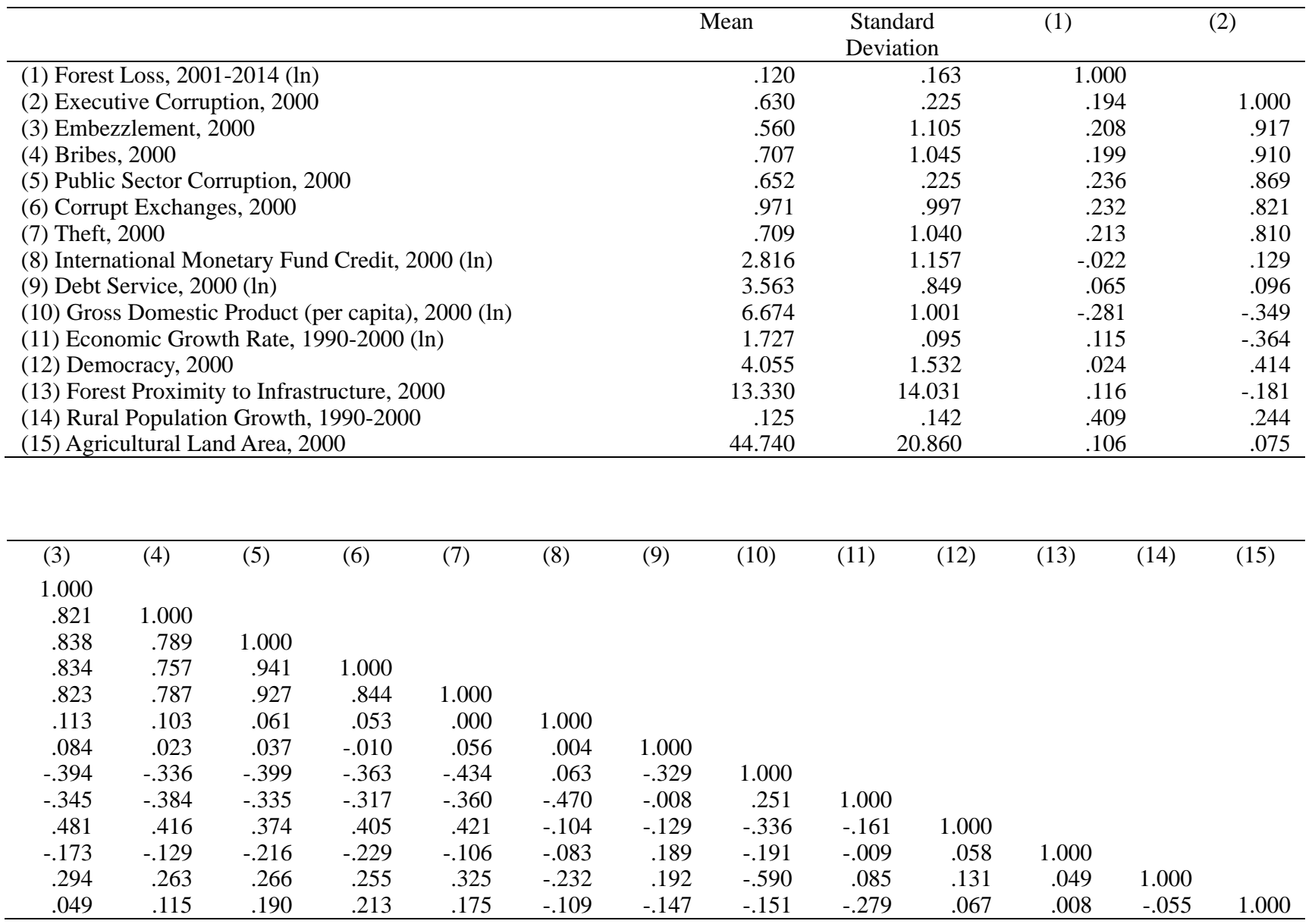

2.4 Independent Variables

Grand/Executive Corruption: According to Dahlberg et al. (2016), this variable measures the extent to which members of the executive branch or their agents grant favors in exchange for bribes, kickbacks, or other material inducements, and how often they steal, embezzle, or misappropriate public funds or other state resources for personal or family use. High numbers of this variable represent high levels of executive corruption (Dahlberg et al. 2016). Based on the above discussion, we should expect higher levels of executive corruption to be associated with higher levels of forest loss. These data, as well as the data for the following three variables, are from the Varieties of Democracy Dataset (Dahlberg et al., 2016). The creators of this dataset index the following two variables to measure the present variable (Dahlberg et al., 2016).

Executive Embezzlement: This variable measures the extent to which the executive sector and their agents steal, embezzle, or misappropriate public and state funds for family or personal use (Dahlberg et al., 2016). This variable is multiplied by negative 1 so that high numbers represent high levels of executive embezzlement.

Executive Bribes: This variable measures the extent to which the executive sector and their agents grant favors in exchange for bribes, kickbacks, or other material inducements (Dahlberg et al., 2016). Again, this variable is multiplied by negative 1 so that high numbers represent high levels of executive bribery.

Petty/Public Sector Corruption: According to Dahlberg et al. (2016), this variable measures the extent to which members of the public-sector grant favors in exchange for bribes, kickbacks, or other material inducements, and how often they steal, embezzle, or misappropriate public funds or other state resources for personal or family use. High numbers of this variable represent high levels of public sector corruption (Dahlberg et al., 2016). Based on the above discussion, we should expect higher levels of executive corruption to be associated with higher levels of forest loss. Again, the creators of this dataset index the following two variables to measure the present variable (Dahlberg et al., 
2016).

Petty/Public Sector Theft: This variable measures the extent to which public sector employees steal, embezzle, or misappropriate public and state funds for family or personal use (Dahlberg et al., 2016). This variable is multiplied by negative 1 so that high numbers represent high levels of executive embezzlement.

Petty/Public Sector Corrupt Exchanges: This variable measures the extent to which public sector employees grant favors in exchange for bribes, kickbacks, or other material inducements (Dahlberg et al., 2016). Again, this variable is multiplied by negative 1 so that high numbers represent high levels of executive bribery.

\subsection{Control Variable Selection and Measurement}

The control variables selected, as well as the time period for which they are measured is based on previous cross-national research (Sommer, 2017; Shandra et al., 2016). The time period for which each control variable is included is in parentheses. First, economic and political factors that may influence forest loss are controlled for. These include GDP per capita (2000), GDP growth (1990-2000), forestry proximity to infrastructure (2000), and democracy (2000) (Ehrhardt-Martinez, Crenshaw, \& Jenkins, 2002; Shandra et al., 2016; Shandra, 2007). Second, the models include several demographic factors, including rural population growth (1990-2000) and agricultural land area (2000) (Rudel \& Roper, 1997). Third, international factors of International Monetary Fund (IMF) loans (2000) and debt service (2000) are included in the models (Bunker, 1985; Shandra et al., 2011). The democracy measure is available from Freedom House (2005), and forest proximity to infrastructure is from the Food and Agricultural Organization Annual Forestry (2015) report. All other variables are available from the World Bank (2015).

\section{Results}

Table 3 includes the ordinary least squares regression estimates of corrupt actions on forest loss. The first number in the table is the unstandardized coefficient, the next is the standardized coefficient, and the last number is the robust standard error in parentheses. All models report one-tailed tests due to the directional nature of the hypotheses (Shandra et al., 2016). Every equation includes variables that represent GDP per capita, economic growth, forestry proximity to infrastructure, democracy, agricultural land area, IMF loans, and debt service. Each equation contains one of the six measures of corruption. Equation (3.1) contains the index of grand or executive corruption, and equation (3.2) and (3.3) contain embezzlement and bribes respectively. Equation (3.4) includes the index of petty or public-sector corruption, equation (3.5) contains corrupt exchanges, and (3.6) includes theft. The models are thus organized to deal with the high levels of correlation among the various corruption measures.

Table 3. Ordinary Least Squares Regression Estimates of Corruption on Forest Loss, 2001- 2014

\begin{tabular}{ccccccc}
\hline & Equation & Equation & Equation & Equation & Equation & Equation \\
& $(3.1)$ & $(3.2)$ & $(3.3)$ & $(3.4)$ & $(3.5)$ & $(3.6)$ \\
\hline
\end{tabular}

\section{Independent Variables}

Executive Corruption, $2000 \quad$.168* 
Corrupt Exchanges, 2000

$.041 * *$

.251

(.017)

Theft, 2000

$.032 *$

.206

$(.018)$

International Monetary Fund

Loans, 2000

$.030 *$

$.030 *$

$.031 *$

$.032 *$

$.031 \%$

$.034 *$

.219

.215

.227

.229

.225

.247

(.016)

(.016)

(.016)

(.016)

(.016)

(.016)

Debt Service, 2000

$\begin{array}{lll}-.012 & -.011 & -.008\end{array}$

$-.009$

$-.007$

$-.008$

$\begin{array}{ll}-.063 & -.059\end{array}$

$-.043$

$-.044$

$-.038$

$-.042$

(.016)

(.023)

(.024)

(.016)

(.023)

(.024)

Gross Domestic Product, 2000

$\begin{array}{ll}-.013 & -.012\end{array}$

$-.015$

$-.007$

$-.009$

$-.011$

$-.079$

$-.071$

$-.089$

$-.043$

$-.058$

$-.065$

(.028)

(.028)

(.028)

(.027)

(.027)

(.028)

Economic Growth Rate, 1990-2000

$$
\begin{gathered}
.574 * * \\
.337
\end{gathered}
$$

Democracy, 2000

$\begin{array}{ll}-.011 & -.013 \\ -.101 & -.121 \\ (.017) & (.018)\end{array}$

Forest Proximity to Infrastructure, 2000

.002
.164
$(.001)$

Rural Population Growth Rate, 1990-2000

$\begin{array}{cc}.412 * & .400 * \\ .356 & .346 \\ (.174) & (.179)\end{array}$

Agricultural Land Area, 1990-2000

Constant

$\begin{array}{cc}.002 * & .002 * \\ .209 & .216 \\ (.001) & (.001) \\ -1.041 * & -.947 * \\ (.480) & (.471)\end{array}$

$$
\begin{gathered}
.583^{* *} \\
.342 \\
(.210) \\
-.010 \\
-.091 \\
(.018)
\end{gathered}
$$

$.558 * *$

.327

(.201)

$-.009$

$-.085$

(.017)

.002

.144

(.001)

$.002 *$

.179

(.001)
$.401 *$

.346

(.179)

$.419 * *$

.362

(.168)

$.002 *$

.001

.184

(.001)

$-1.083$

(.491)

$.413 * *$

.357

(.174)

(.001)
$-.980 *$
(.489)

(.001)
$.544 * *$

.319

(.196)

$-.010$

$-.096$

(.017)

$.002 *$

.178

(.001)

$.570 * *$

.334

(.208)

$-.008$

$-.078$

(.017)

.002

.142

(.001)

$.411 * *$

.355

(.171)

$.002 *$

.197

(.001)

$-.992 *$

(.496) 


\begin{tabular}{|c|c|c|c|c|c|c|c|}
\hline R-Squared & & .282 & .282 & .278 & .288 & .286 & .273 \\
\hline Number of Countries & $\Gamma$ & 87 & 87 & 87 & 87 & 87 & 87 \\
\hline $\begin{array}{l}\text { Highest Variance Inflation } \\
\text { Score }\end{array}$ & Factor & 2.36 & 2.37 & 2.36 & 2.41 & 2.38 & 2.38 \\
\hline $\begin{array}{l}\text { Mean Variance Inflation } \\
\text { Score }\end{array}$ & Factor & 1.61 & 1.64 & 1.60 & 1.59 & 1.60 & 1.61 \\
\hline Breusch-Pagan Test & & $37.81 * * *$ & $36.73 * * *$ & $37.87 * * *$ & $38.28 * * *$ & $36.58 * * *$ & $35.23 * * *$ \\
\hline
\end{tabular}

\section{Notes.}

a) $*$ indicates $\mathrm{p}<.05$, ** indicates $\mathrm{p}<.01$, and $* * *$ indicates $\mathrm{p}<.001$ for a one-tailed test.

b) The first number is the unstandardized coefficient, the second number is the standardized coefficient, and the third number in parentheses is the robust standard error.

Across table 3, the coefficients that represent each corruption index and each corrupt action—bribes, embezzlement, corrupt exchanges, and theft - are positive and statistically significant, suggesting that higher levels of all corrupt actions tested are associated with increased forest loss. This finding supports previous research that suggests corrupt acts increase forest loss due to both grand and petty corruption (Currey \& Ruwindrijarto, 2001; Palo, 2004; Sommer, 2017).

Additionally, several other factors are associated with forest loss. First, the coefficients that represent economic growth are positive and significant in every equation, suggesting that higher levels of economic growth correspond with more forest loss, which is most likely because nations in economic upturns tend to invest in activities thatincrease forest loss(Rudel, 1989; Jorgenson, 2006). Second, the coefficients that represent IMF loans are positive and significant in every equation. This is consistent with research by Shandra et al. (2011), which argues that IMF loans increase forest loss due to policies that cut state spending for conservation. Third, the coefficients that represent rural population growth are associated with more forest loss, possibly due to resource shortages that often accompany growing rural populations (Jorgenson \& Burns, 2007; Rudel, 2016). Fourth, the coefficients that represent agricultural land area are associated with more forest loss in four of six equations. These findings support previous evidence showing that agricultural expansion can result in forests being cleared for crop expansion (Rudel et al., 2009).

There are also some non-significant findings. First, GDP per capita is not significant. This is surprising as previous research has found level of economic development to be related to forest loss. However, in this analysis, it is possible that the effects of economic growth are more important. Second, in four of six equations, forest proximity to infrastructure fails to reach levels of statistical significance. Third, democracy is not associated with forest loss.

\section{Discussion}

This study examines how corrupt actions, including bribes, embezzlement, corrupt exchanges, and theft, affect forests. In doing so, the analysis finds all four grand and petty corrupt actions to be related to increased forest loss. Therefore, this study begins to show support for the idea that corrupt acts, regardless of the act itself, are related to increased forest loss cross-nationally in low- and middle-income nations. The main findings demonstrate the importance of considering corrupt actions at both the grand and petty level when accessing how corruption impacts the natural environment (Bradshaw, 1987; London \& Smith, 1988; Smith, 1996).

These results have important implications for enhancing government transparency in forestry. States should aim to adopt anti-corruption policies (Dadge \& Thomas, 2013; Callister, 1999; Kishor \& Rosenbaum, 2012). However, as the present analysis shows, such solutions may not realistically reduce forest loss if they are specific to a particular corrupt act (Kishor \& Damania, 2007; Gore et al., 2013). Anti-corruption legislation must therefore take a bottom up as well as a top down approach in the forestry sector to address different corrupt actions simultaneously. At the top, state leaders and public officials in low- and middle-income nations can aim to remove logging concessions and implement internal processes to punish corrupt officials (Bryant \& Bailey, 1997; Callister, 1999; Goncalves, et al., 2012). At the bottom, the state can increase the wages of forestry officials, so they do not need to engage in corrupt exchanges and theft to make ends meet (Koyuncu \& Yilmaz, 2009; Siebert \& Elwert, 2004; Miller, 2011). It may also be helpful to break up corrupt networks on the ground through providing monetary incentives for turning in corrupt officials and the loggers they partner with (Miller, 2011).

There are some limitations of this study that should be reviewed. First, due to data availability, this study uses a sample of only 87 low- and middle-income nations. Future analyses should include all low- and middle-income nations when data become available. Second, although this study measures corrupt acts in the best way possible given current cross-national data, better measurement of corrupt acts is necessary for researchers to get a more precise understanding of how it effects forest loss. Unfortunately, because the data represent corrupt actions as a whole, and not specifically in the forestry sector, we can only rely on previous research to formulate how corrupt actions would translate into forest 
loss on the ground. The mechanisms discussed in this article are based on qualitative research in the nations involved and represent corruption in the forestry sector specifically. Although the independent variables in this analysis represent corrupt acts in all sectors, we can assume that nations with high levels of corrupt acts overall will generally have higher levels of corrupt acts in the forestry sector as well. However, future analyses will benefit from disaggregated corruption data that measures corrupt acts in each sector separately. Until these data are available, the Varieties of Democracy (2016) corruption data used in this article represent the best measure of disaggregated corruption.

Despite the limitations of the data, one conclusion remains clear, more scholarly attention should be paid to specific corrupt acts rather than corruption as a whole to better identify the factors that contribute to it and to develop more informative policy suggestions. Understanding the differences between corrupt acts should be of principal importance because of their detrimental impacts on forests. At the very least, corruption in cross-national research should be conceptualized as a series of actions and behaviors that undermine forestry conservation.

\section{Acknowledgements}

I want to thank John Shandra, Kathleen Fallon, Ian Roxborough, and Andrew Hargrove for their help with this article.

\section{References}

Agrawal, A. (2007). Forests, governance, and sustainability: common property theory and its contributions. International journal of the commons 1(1), 111-136. Igitur, Utrecht Publishing \& Archiving Services for IASC.

Aisbett, E., Doupe, P., \& Tacconi, L. (2013). Disequilibrium adjustment and the rate of tropical deforestation. Crawford School Research Paper No. 13-10. https://doi.org/10.2139/ssrn.2343457

Allison, P. D. (1999). Multiple regression: A primer. Pine Forge Press. Thousand Oaks, California.

Arias, G. (2005). Identificación y priorización de los actores de la ilegalidad [Identification and prioritization of the actors in illegality]. San José, Costa Rica: Proyecto Fortalecimiento Insti- tucional para la Ejecución de la Estrategia Nacional de Control de la Tala Ilegal de Recursos Forestales en Costa Rica (SINAC-FAO-TCP/COS/3003).

Barbier, E. B., Damania, R., \& Léonard, D. (2005). Corruption, trade and resource conversion. Journal of Environmental Economics and Management, 50(2), 276-299. https://doi.org/10.1016/j.jeem.2004.12.004

Barrett, C. B., Gibson, C. C., Hoffman, B., \& McCubbins M. D. (2006). The complex links between governance and biodiversity. Conservation biology, 20(5), 1358-1366. https://doi.org/10.1111/j.1523-1739.2006.00521.x

Bradshaw, Y. W. (1987). Urbanization and underdevelopment: A global study of modernization, urban bias, and economic dependency. American Sociological Review, 224-239. https://doi.org/10.2307/2095451

Bryant, R. L., \& Bailey, S. (1997). Third world political ecology. Routledge. London, UK.

Bulte, E. H., Damania, R., \& Lopez, R. (2007). On the gains of committing to inefficiency: corruption, deforestation and low land productivity in Latin America. Journal of Environmental Economics and Management, 54(3), 277-295. https://doi.org/10.1016/j.jeem.2007.05.002

Bunker, S. G. (1985). Underdeveloping the Amazon: Extraction, unequal exchange, and the failure of the modern state. University of Chicago Press.

Butler, R. (2013). The Congo. Mongabay.com. https://rainforests.mongabay.com/congo/deforestation.html

Callister, D. (1999). Corrupt and illegal activities in the forestry sector: Current understandings, and implications for world bank forest policy: Draft for discussion. World Bank, Washington.

Cavanaugh, C. (2012). Unready for REDD? Lessons from corruption in Ugandan conservation area. U4 Brief 2012:3. Christian Michelsen Institute: Bergen. Chicago

Coppedge, M., Gerring, J., Lindberg, S. I., Skaaning, S. E., Teorell, J., Andersson, F., ... Pernes, J., (2016). V-Dem Methodology v6.

Currey, D., \& Ruwindrijarto, A. (2001). Introduction. In Environmental Investigation Agency (EIA) and Telapak (eds.), Timber trafficking: Illegal logging in Indonesia, South East Asia and international consumption of illegally sourced timber. London: Environmental Investigation Agency and Telapak.

Dage, D., \& Thomas, A. (2013). Corruption and the environment. United Nations Information Service. United Nations, Vienna.

Dahlberg, S., Holmberg, S., Rothstein, B., Khomenko, A., \& Svensson, R. (2016). The Quality of Government Basic Dataset (version January 2016), University of Gothenburg: The Quality of Government Institute, http://www.qog.pol.gu.se 
Debroux, L., Hart, T., Kaimowitz, D., Karsenty, A., \& Topa, G. (2007). Forests in post-conflict Democratic Republic of Congo: Analysis of a priority agenda (pp. xxii-82p). The World Bank CIRAD Bogor, Indonesia: CIFOR.

Ehrhardt-Martinez, K., Crenshaw, E. M., \& Jenkins, J. C. (2002). Deforestation and the Environmental Kuznets Curve: A Cross-National Investigation of Intervening Mechanisms. Social Science Quarterly, 83(1), 226-243. https://doi.org/10.1111/1540-6237.00080

Finer, M., Jenkins, C. N., Sky, M. A. B., \& Pine, J. (2014). Logging concessions enable illegal logging crisis in the Peruvian Amazon. Scientific reports, 4, 4719. https://doi.org/10.1038/srep04719

Food and Agriculture Organization (2015). Global Forest Resources Assessment. Food and Agriculture Organization Forestry Paper. Rome: United Nations.

Gore, M., Ratsimbazafy, L. J., \& Lute, M. L. (2013). Rethinking corruption in conservation crime: insights from Madagascar. Conservation Letters, 6(6), 430-438. https://doi.org/10.1111/conl.12032

Grainger, A. (2008) Difficulties in tracking the long-term global trend in tropical forest area. Proceedings of the National Academy of Sciences 105(2), 818-823. https://doi.org/10.1073/pnas.0703015105

Halkos, G. M., Sundstrom, A., \& Tzeremes, N. (2013). Environmental performance and quality of governance: a non-parametric analysis of the NUTS 1-regions in France, Germany and the UKIn: MPRA Working Paper 48890.

Hansen, M. C., Stehman, S. V., \& Potapov, P. V. (2010). Quantification of global gross forest cover loss. Proceedings of the National Academy of Sciences, 107(19), 8650-8655. https://doi.org/10.1073/pnas.0912668107

House, F. (2005). Freedom in the World 2005: civic power and electoral politics. New York: Freedom House.

Iverson, V., Chhetry, B., Francis, P., Gurung, M., Kafle, G., Pain, A., \&Seeley, J. (2005). High Value Forests, Hidden Economies and Elite Capture: Evidence from Forest User Groups in Nepal's Terai. Ecological Economics, 58(1), 93-107. https://doi.org/10.1016/j.ecolecon.2005.05.021

Jorgenson, A. K. (2006). The Transnational Organization of Production and Environmental Degradation: A CrossNational Study of the Effects of Foreign Capital Penetration on Water Pollution Intensity, 1980-1995. Social Science Quarterly, 87(3), 711-730. https://doi.org/10.1111/j.1540-6237.2006.00405.x

Jorgenson, A. K., \& Burns, T. J. (2007). Effects of Rural and Urban Population Dynamics and National Development on Deforestation in Less-Developed Countries, 1990-2000. Sociological Inquiry, 77(3), 460-482. https://doi.org/10.1111/j.1475-682X.2007.00200.x

Kishor, N., \& Damania, R. (2007). Crime and justice in the Garden of Eden: improving governance and reducing corruption in the forestry sector. The many faces of corruption. The World Bank, Washington, DC.

Koyuncu, C., \& Yilmaz, R. (2009). The impact of corruption on deforestation: a cross-country evidence. The Journal of Developing Areas, 42(2), 213-222. https://doi.org/10.1353/jda.0.0010

Koyuncu, C., \& Yilmaz, R. (2013). Deforestation, corruption, and private ownership in the forest sector. Quality \& Quantity, 47(1), 227-236. https://doi.org/10.1007/s11135-011-9513-2

Laurance, W. F. (2004). The perils of payoff: corruption as a threat to global biodiversity. Trends in Ecology \& Evolution, 19(8), 399-401. https://doi.org/10.1016/j.tree.2004.06.001

Laurance, W. F. (2007). Forest destruction in tropical Asia. Current Science, 93(11), 1544-1550. https://www.jstor.org/stable/i24099056

Laurance, W. F., Albernaz, A. K. M., \& Da Costa, C. (2001). Is deforestation accelerating in the Brazilian Amazon? Environmental Conservation, 4, 305-311. https://doi.org/10.1017/S0376892901000339

London, B., \& Smith, D. A. (1998). Urban bias, dependence, and economic stagnation in noncore nations. American Sociological Review, 454-463. https://www.jstor.org/stable/2095652

Meehan, F., \& Tacconi, L. (2017). A framework to assess the impacts of corruption on forests and prioritize responses. Land Use Policy, 60, 113-122. https://doi.org/10.1016/j.landusepol.2016.10.021

Meyer, A. L., Van Kooten, G. C., \& Wang, S. (2003). Institutional, social and economic roots of deforestation: a cross-country comparison. International Forestry Review, 5(1), 29-37. https://doi.org/10.1505/IFOR.5.1.29.17427

Miles, L., Adrian, C., Newton, DeFries, R. S, Ravilious, C., May, I., Blyth, S., Kapos, V., \& Gordon, J. E. (2006). A global overview of the conservation status of tropical dry forests." Journal of Biogeography, 33(3), 491-505. https://doi.org/10.1111/j.1365-2699.2005.01424.x

Miller, M. (2011). Persistent Illegal Logging in Costa Rica: The Role of Corruption Among Forestry Regulators. The 
Journal of Environment and Development, 20(2), 50-68. https://doi.org/10.1177/1070496510394319

Oliveira, P. J. C., Asner, G. P., Knapp, D. E., Almeyda, A., Galván-Gildemeister, R., Keene, S., ... Smith, R. C. (2007). Land-use allocation protects the Peruvian Amazon. Science, 317(5842), 1233-1236.

Palo, M. (2004). How Does Corruption Drive Deforestation in the Tropics? Forest Research Institute METLA Working Paper, Helsinki.

Prager, J. C., \& Thisse, J. F. (2012). Economic geography and the unequal development of regions (Vol. 59). Routledge.

Putz, F. E., \& Romero, C. (2015). Futures of tropical production forests (Vol. 143). Bogor, Indonesia: CIFOR.

Robbins, P. (2000). The rotten institution: corruption in natural resource management. Political Geography, 19(4), 423-443. https://doi.org/10.1016/S0962-6298(99)00087-6

Rudel, T. K. (1989) Population, Development, and Tropical Deforestation: A Cross-National Study. Rural Sociology, 54(3), 327-338.

Rudel, T. K. (2017). The dynamics of deforestation in the wet and dry tropics: a comparison with policy implications. Forests, 8(4), 108. https://doi.org/10.3390/f8040108

Rudel, T. K., \& Roper, J. (1997). The paths to rain forest destruction: crossnational patterns of tropical deforestation 1975-1990. World Development, 25(1), 53-65. https://doi.org/10.1016/S0305-750X(96)00086-1

Rudel, T. K., Schneider, L., Uriarte, M., Turner, B. L., DeFries, R., Lawrence, D., ... Birkenholtz, T. (2009). Agricultural intensification and changes in cultivated areas, 1970-2005. Proceedings of the National Academy of Sciences, 106(49), 20675-20680. https://doi.org/10.1073/pnas.0812540106

Rudel, T. K., Sloan, S., Chazdon, R., \& Grau, R. (2016). The drivers of tree cover expansion: Global, temperate, and tropical zone analyses. Land Use Policy, 58, 502-513. https://doi.org/10.1016/j.landusepol.2016.08.024

Sears, R. R., \& Pinedo-Vasquez, M. (2011). Forest policy reform and the organization of logging in Peruvian Amazonia. Development and Change ,42(2), 609-631. https://doi.org/10.1111/j.1467-7660.2011.01697.x

Severin, A. (2010). Deforestation Threatens South With Famine. Inter Press Service.

Shandra, J. M. (2007). Economic Dependency, Repression, and Deforestation: A Quantitative, Cross-National Analysis. Sociological Inquiry, 77(4), 543-571. https://doi.org/10.1111/j.1475-682X.2007.00209.x

Shandra, J. M., McKinney, L. A., Leckband, C., \& London, B. (2010). Debt, structural adjustment, and biodiversity loss: a cross-national analysis of threatened mammals and birds. Human ecology review, 17(1), 18-33. https://www.jstor.org/stable/24707512

Shandra, J. M., Rademacher, H., \& Coburn, C. (2016). The World Bank and organized hypocrisy? A cross-national analysis of structural adjustment and forest loss. Environmental Sociology, 2(2), 192-207. https://doi.org/10.1080/23251042.2016.1160471

Shandra, J. M., Shircliff, E., \& London, B. (2011). The International Monetary Fund, World Bank, and structural adjustment: A cross-national analysis of forest loss. Social Science Research, 40(1), 210-225. https://doi.org/10.1016/j.ssresearch.2010.08.004

Siebert, U., \& Elwert, G. (2004). Combating Corruption and Illegal Logging in Bénin, West Africa: Recommendations for Forest Sector Reform. Journal of Sustainable Forestry, 19(1-3), 239-261. https://doi.org/10.1300/J091v19n01_11

Smith, D. A. (1996). Third World Cities in Global Perspective: The Political Economy of Uneven Development. Boulder, CO: Westview Press.

Sommer, J. M. (2017). Grand and petty corruption: a cross-national analysis of forest loss in low-and middle-income nations. Environmental Sociology, 3(4), 414-426. https://doi.org/10.1080/23251042.2017.1348569

Søreide, T. (2007). Forest concessions and corruption. U4 ISSUE 3:2007. Bergen: Christian Michelsen Institute.s[ep:

Speechly, H., \& Van Helden, F. L. I. P. (2012). 3.2 Forest governance in southeast asia. Moving Forward With Forest Governance, 101

Straumann, L. (2014). Money logging: on the trail of the Asian timber mafia. Bergli Book, Schwabe AG. Basel, Switzerland.

Sundström, A. (2016a). Understanding illegality and corruption in forest management: A literature review. Working Paper Series 2016, University of Gothenburg.

Sundström, A. (2016b). Corruption and violations of conservation rules: A survey experiment with resource users. World 
Development, 85, 73-83. https://doi.org/10.1016/j.worlddev.2016.04.011

Tabachnick, B. G., \& Fidell, L. S. (2013). Using Multivariate Statistics. $6^{\text {th }}$ ed. Boston, MA: Pearson.

Tacconi, L., Downs, F., \& Larmour, P. (2009). Anti-corruption policies in the forest sector and REDD+. Realising REDD+: National strategy and policy options, 163-174. Bogor, Indonesia: CIFOR.

Transparency International (2018). Forestry. Transparency International. Berlin, Germany. https://www.transparency.org/topic/detail/forestry

Urrunaga, J. M., Johnson, A., Orbegozo, I. D., \& Mulligan, F. (2012). The Laundering Machine-How Fraud and Corruption in Peru's Concession System are Destroying the Future of its Forests. Washington, DC: Environmental Investigation Agency.

Varieties of Democracy. (2016). V-Dem: Global Standards, Local Knowledge. V-Dem Institute, University of Gothenburg and Helen Kellogg Institute for International Studies, University of Notre Dame. https://www.v-dem.net/en/data/data-version-6-2/

World Bank. (2015). World Development Indicators. Washington, DC: World Bank. http://data.worldbank.org

World Bank. (2018). World Development Indicators. Washington, DC: World Bank. http://data.worldbank.org

World Resources Institute. (2016). World Resources Institute Global Forest Watch. Forests. Washington, DC: World Resources Institute. http://www.wri.org/resources/data_sets

York, R., Rosa, E. A., \& Dietz, T. (2003). Footprints on the Earth: The Environmental Consequences of Modernity. American Sociological Review, 68, 279-300. https://doi.org/10.2307/1519769

\section{Notes}

Note 1: The nations in this sample include: Albania; Algeria; Armenia; Azerbaijan; Bangladesh; Belarus; Benin; Bhutan; Bolivia; Botswana; Brazil; Bulgaria; Burundi; Cameroon; Central African Republic; Chad; China; Colombia; Comoros; Republic of the Congo; Costa Rica; Cote d'Ivoire; Dominican Republic; Ecuador; Egypt; El Salvador; Fiji; Gabon; Georgia; Ghana; Guinea; Guinea-Bissau; Guyana; Honduras; India; Indonesia; Iran; Jamaica; Jordan; Kazakhstan; Kenya; Kyrgyz Republic; Laos; Lebanon; Macedonia; Madagascar; Malawi; Malaysia; Mali; Mauritius; Mexico; Mongolia; Morocco; Mozambique; Nepal; Nicaragua; Pakistan; Panama; Papua New Guinea; Paraguay; Peru; Philippines; Romania; Senegal; Sierra Leone; Sri Lanka; Sudan; Swaziland; Tajikistan; Tanzania; Thailand; Togo; Tunisia; Turkey; Turkmenistan; Uganda; Ukraine; Uzbekistan; Vanuatu; Vietnam; and Zimbabwe

Note 2: These data are an improvement from previous data because they are based on satellite imagery, and therefore can confidently be compared across nations. The data are derived using the 75 percent canopy cover level (Miles et al. 2006).

Note 3: It is important to note that when democracy is removed from the equations, all findings remain substantively similar.

\section{Copyrights}

Copyright for this article is retained by the author(s), with first publication rights granted to the journal.

This is an open-access article distributed under the terms and conditions of the Creative Commons Attribution license which permits unrestricted use, distribution, and reproduction in any medium, provided the original work is properly cited. 